\title{
Amish Economic Transformations: New Forms of Income and Wealth Distribution in a Traditionally "Flat" Community
}

\author{
Amyaz A. Moledina, Associate Professor ${ }^{1}$ \\ Department of Economics \\ College of Wooster
}

David L. McConnell, Professor

Department of Sociology and

Anthropology

College of Wooster

\author{
Stephanie A. Sugars \\ Summer Research Assistant \\ College of Wooster \\ Bailey R. Connor \\ Summer Research Assistant \\ College of Wooster
}

\begin{abstract}
The basic contours of the Amish economic transformation over the past few decades have been well documented, including the demographic squeeze that pushed many Amish out of farming, their embrace of cottage industries and, to a lesser extent, factory labor, and the social and cultural dilemmas created by successful entrepreneurship. Yet the effects of increasing market entanglement on the distribution of income and assets in Amish communities are still poorly understood. In this exploratory study, we draw on publicly available data from the U.S. Census, the Ohio Amish Directory, and records from real estate transactions to map out the distribution of income and land wealth in one predominantly Amish-populated Census Tract in Holmes County, $\mathrm{OH}$. Our findings illustrate economic differentiation within the Amish community, as well as the ways in which affiliation and church leadership are associated with land holdings. Our case study raises important questions about growing economic inequalities that merit further exploration.
\end{abstract}

\section{Keywords}

Amish; economics; wealth; income; land; U.S. Census; inequality; Holmes County, OH

\section{Acknowledgements}

The authors acknowledge the financial support of College of Wooster's "Summer Explorations in Interdisciplinary Research” program funded by the Dean of Faculty's office. We also appreciate the comments provided by reviewers. All errors and omissions are ours. 


\section{Introduction}

The rise in Amish entrepreneurship and the shift from plows to profits in just over one generation is without question the most remarkable chapter yet in the ongoing story of the Amish struggle with modernity. The key themes of this economic transformation have been richly documented in the scholarly literature. They include the combination of internal and external pressures that led Amish to lay down their plows (Kraybill 2001), the tradeoffs associated with factory labor versus cottage industry (Meyers 1994; Olshan 1991), and the cultural factors that both facilitated and constrained the growth of Amish businesses (Kraybill and Nolt 2004). The extraordinary growth of the Amish population and the number of Amish settlements in a postfarming world (Donnermeyer and Cooksey 2010) has validated Olshan's response to the prediction that the Amish would die out as a people if they ever left farming: "The survival of the Amish as a distinct group is much less problematic than their ability to perpetuate the values of an agrarian society once agriculture is no longer the foundation of economic life” $(1991,378)$.

The social and cultural consequences of the shift away from farming, to which Olshan alludes in the quote above, have also been analyzed in ethnographic studies of the largest Amish settlements. Kraybill and Nolt's (2004) in-depth study of businesses in the Lancaster, PA, settlement, for example, describes changes in child-rearing practices and gender roles, new pressures on Amish parochial schools, shifts in church life (increase in population density and decrease in the geographic size of church districts), and the growing influence of businessmen on church Ordnung, as well their representation in the ranks of ordained leaders. Nolt and Meyers (2007) chronicle the rise of Amish diversity in Indiana settlements, including the effects of work in the RV industry, while Johnson-Weiner (2010) maps out migration histories and the varieties of cultural and religious patterning for Amish groups in New York State. Hurst and McConnell (2010) call attention to the varieties of educational choices made by Amish in the Holmes County $(\mathrm{OH})$ Settlement, as well as the rise of Amish millionaires and the transformation of consumerism and leisure time. Deep ambivalence among the Amish themselves about the longterm implications of these changes was captured in a 2007 Family Life article on "The Big I" that warned of growing individualism in their communities.

Less well understood, however, are the effects of increasing market entanglement on the economics of Amish families and communities themselves. What is the spread of income and wealth distribution in Amish settlements, and how has it changed over time? How do average income, land values, and acreage owned vary across affiliations or by church standing (member versus ordained leader)? Does it make sense to describe a portion of the Amish as "living in poverty"? These and other questions are important to ask in light of the growing economic disparities in the United States as a whole (Putnam 2013). The Amish case raises larger questions about whether religion and culture can insulate a tradition-oriented group from the more deleterious effects of capitalism even as their lives become increasingly intertwined with and dependent on market forces. 
In this exploratory article, we draw on publicly available data from the U.S. Census, the Ohio Amish Directory, and records from real estate transactions to map out the distribution of income and land wealth in one predominantly Amish-populated Census Tract in Holmes County, $\mathrm{OH}$. Our modest goal was to ascertain whether an economic profile of the Amish could be fashioned by triangulating data from the U.S. Census, the Ohio Amish Directory, and the Holmes County Auditor's website, and if so, to determine what can be learned about economic differentiation in the Amish community.

\section{Growing Economic Differentiation in a Traditionally “Flat” Society?}

I was at a farm auction last week and, you know, the common people start buying tools about 10 am. Then about 11:15 the heavy hitters roll in. They just carry themselves differently.... - Old Order Amish farmer

One of the hallmarks of Amish society has long been its emphasis on the good of the community over individual expression and interests. Key symbols and structures of Amish life reinforce this sense of social solidarity. Amish dress keeps everyone on the same footing because it minimizes choices that are designed to accentuate the individual. Similarly, the small size of church districts, the practice of hosting church in the home, and the expectation that church services will be attended by horse and buggy send a strong message that everyone is equal in the eyes of God. Ending school after eight grades homogenizes not only educational achievement but to some extent occupation, since it eliminates careers in professions such as law or medicine. According to Kraybill, the presence of these social leveling mechanisms means "the conventional markers of social class-education, occupation, and income-have less impact in Amish society," resulting in a social structure that is "relatively flat, compared to the hierarchical class structure of postindustrial societies” (2001, 109-10).

The tradition of farming has been central to mitigating the development of a class structure in Amish society. John Hostetler was one of the first scholars to note how Amish ties to the land corresponded to economic structures: "Egalitarian patterns," he argued, are "manifest in socially approved means of subsistence, production and consumption” $(1993,14)$. The move away from farming and the subsequent "mini-industrial revolution" among the Amish, however, has shaken the foundations of this model of rural togetherness and economic homogeneity in ways that we are only beginning to understand. Though egalitarianism may still exist as a cultural ideal, several strands of scholarship have begun to explore the consequences of the shift in economic livelihoods.

One set of studies explores the impact of tourism on Amish communities and the complex ways in which they both resist and accommodate the practice of "selling the Amish," to quote the title of a recent addition to this literature (Trollinger 2012). Studies in this category have tended to focus on the love/hate relationship the Amish have with tourism and with both its positive and negative effects. Some have called attention to the practical matter of increases in congestion and 
likelihood of buggy accidents (Kreps, et al. 1997) while others have seen tourism as a key threat to Amish "cultural authenticity” (Testa 1992). Still others have pointed out that tourist motives tend to revolve around shopping (Meyers 2003) and that Amish businesses are increasingly dependent on the tourist industry; for example, 10 percent of Amish businesses in Lancaster County report sales to tourists account for more than half of their retail volume (Kraybill and Nolt 2004, 154). Yet the implications of Amish participation in the tourist industry on economic stratification in their own communities remain largely unexplored.

A second important vein of research has explored the causes behind the extraordinary growth and success of Amish entrepreneurs, as well as the various forms their businesses take. The definitive study in this area is still Kraybill and Nolt's (2004) Amish Enterprise. Based on 114 returned surveys and 35 interviews with Amish entrepreneurs, the authors were able to map out the size and types of Amish enterprises, their annual sales, the cultural resources and constraints at work in their businesses, and the ways these Amish enterprises navigate the market, cope with government regulations, and interface with consumers. In contrast, Wesner's (2010) study, Success Made Simple, based on 60 interviews with owners of medium to large businesses, focused primarily on the ingredients underlying entrepreneurial success for the Amish. More recently, a popular version of this literature has also emerged, as seen in titles such as Money Secrets of the Amish (Kraker 2011).

A third, and related, set of studies asks how Amish enterprise impacts local and regional economies and even revitalizes depressed areas. In a study of 67 Pennsylvania counties, ChristieSearles (2012) found that the presence of Amish communities had a significant effect on per capita incomes, while Johnson-Weiner (2012) discusses the positive effects of Amish settlements on local economies in New York. The flip side of the coin is that Amish are increasingly vulnerable to the vagaries of regional and national economic swings. The 2010 economic downturn, for instance, severely affected adult breadwinners in northern Indiana when the RV industry tanked, and some church leaders made the unprecedented decision of allowing heads of household to collect unemployment benefits. On the whole, though, studies of tourism and Amish enterprise have highlighted the tremendous success of Amish-owned businesses and their key role in local economic revitalization.

The Amish may have paid a high price for this transformation, however, if "high land values and productive businesses are disturbing the egalitarian nature of Amish society" (Kraybill 2001, 109) and if they are tipping "the delicate balance of power preserved by many years of rural life” (Kraybill and Nolt 2004, 253). Anecdotally, we know that there is growing awareness of economic distinctions among the Amish themselves. Hurst and McConnell (2010), for example, devote a section of their chapter on work and occupations to the dangers of wealth. They report a modest but growing awareness of economic disparities within Amish society, as illustrated, for example, by comments about the "uppity class Amish.” They also point out that there is a noticeable economic gap between the most conservative and more liberal Amish; the former are much more likely to be day laborers who work for Amish entrepreneurs from 
"higher” churches. Similarly, Kraybill, Johnson-Weiner, and Nolt $(2013,410)$ argue that the desire by some business owners to be "unbridled by church regulations" is one of the most serious challenges to the Amish world. In this study, then, our goal was to engage these qualitative observations with empirical data to provide a more full-bodied portrait of the Amish economic transformation.

\section{Locating the Amish: Methodological Considerations}

Only a few researchers have turned to the U.S. Census to study the Amish. This is mostly because the Census does not collect data on religious affiliation. Two studies have tried to use the Census to understand Amish demography, while another used the Census to develop a theory about educational choices within the Amish community. The earliest study conducted by the Applied Population Lab at the University of Wisconsin-Madison used decennial Census data to try to estimate the Amish population in Wisconsin. After observing that many Amish reported their ancestry as Pennsylvania German, the Lab used ancestry as a marker of Amish identity (Applied Population Lab 2002). They also collected data on plumbing facilities, access to vehicles, and telephone service as an alternative way of identifying the Amish in the Census. Ultimately, however, they concluded that all of these measures were less than satisfactory ways of locating the Amish in the U.S. Census.

By contrast, Bailey and Collins’ (2009) approach was more fruitful. They were interested in using the Amish as a control group to refute the hypothesis that the U.S. baby boom was caused by improvements in household technology. Instead of using the decennial Census for a state, they identified Amish in a IPUMs sample of the decennial Census. They compared fertility rates for non-Amish and "likely Amish" by using language spoken at home as a marker. The "likely Amish" were also cross-referenced by their answers to questions about household technologies such as telephones and electrification, as well as geography.

The final study by Wang (2009) uses the theory of club goods to explain educational choices within the Amish community in Ohio, Pennsylvania, and Indiana. Like Bailey and Collins, Wang uses "language spoken at home," specifically Pennsylvania Dutch, as a marker to identify the Amish. Language spoken at home thus seems to be the most promising marker of the Amish identity in the U.S. Census, though it does not take into account that some conservative Mennonite communities also speak Pennsylvania Dutch. Therefore, Bailey and Collins (2009) call the Census group that speaks Pennsylvania Dutch, "likely Amish.”

More reliable demographic studies of the Amish use the periodically published and settlement-specific Amish Directories as a source for calculating the total population and other variables (Wasao and Donnermeyer 1992; Donnermeyer and Cooksey 2010). Even this is an imperfect measure, however, since the very conservative affiliations, such as the Swartzentrubers, refuse to participate in the directory. Studies of the Amish that use real estate data are also rare, though Markle and Pasco (1977) draw on data from both Amish directories 
and personal property tax records to evaluate the relationship between wealth and fertility rates among the Indiana Amish. In this study, we are less interested in demography, but more interested in income and wealth distribution within and between Amish orders. Our study combines methods and sources to explore aggregate economic differentiation within the Amish community, as well as the ways in which affiliation and church leadership are associated with land holdings. We acknowledge the limitation of using any one source and therefore triangulate data from the U.S. Census, the Ohio Amish Directory, and the Holmes County auditor's web site to corroborate our findings.

Our goal in this article is to describe aggregate economic differentiation across and within the Amish community. Our analysis looks at measures of income (household income) and wealth (land values). Looking at both income and wealth allows us to distinguish between flows and stocks of economic well-being. We expect that a community that eschews wealth accumulation would have a uniform distribution of income with a smaller standard deviation compared to the non-Amish community. In addition, we expect that there should be very little economic assistance coming from the state (Kraybill 2003). For wealth, which is proxied by land values, we expect to see similar distributions to that of income and relatively low differentiation between church leadership and members.

\section{Obtaining Income Data from the Census}

The Holmes County, OH, population is $40.71 \%$ Amish, the largest concentration of Amish relative to non-Amish of any U.S. county (Donnermeyer, Anderson, and Cooksey 2013, 100). Yet because Holmes County is divided into eight Census Tracts, it is possible to locate Census Tracts with much higher percentages of Amish in the central and eastern parts of the county (see Figure 1). In the absence of individual data on the Amish, we used data aggregated in the American Community Survey (A.C.S.). The A.C.S. is an annual sample survey. The Census Data extraction tool provides five-year estimates of data for geographic areas with populations less than 20,000, and three and five year estimates for populations less than 65,000. The Census Tracts within Holmes County number well under 20,000 inhabitants, so we used the A.C.S. five year estimates, from 2006 to 2010. We also benchmarked the aggregate data to Ohio and the United States, for which we also used the A.C.S. five year estimates.

The A.C.S. estimates are aggregated data collected evenly throughout the year. The numbers are averages over that time period (i.e. 2010 numbers are the mean for the time period between 2006 and 2010). For areas experiencing little change, estimates do not vary much. But the multi-year estimates are likely to lag when there are sizable changes over a short period of time. The benefit of using the multi-year estimates versus one year estimates, particularly for areas with smaller populations, is higher reliability (U.S. Census Bureau 2008). For comparisons with the year 2000, we used precise Census data rather than estimates, as this data has already been made publicly available, serving as a better comparison than a point estimate would. 


\section{Figure 1: Holmes County with Census Tracts and the Percentage of Population that is Likely Amish}

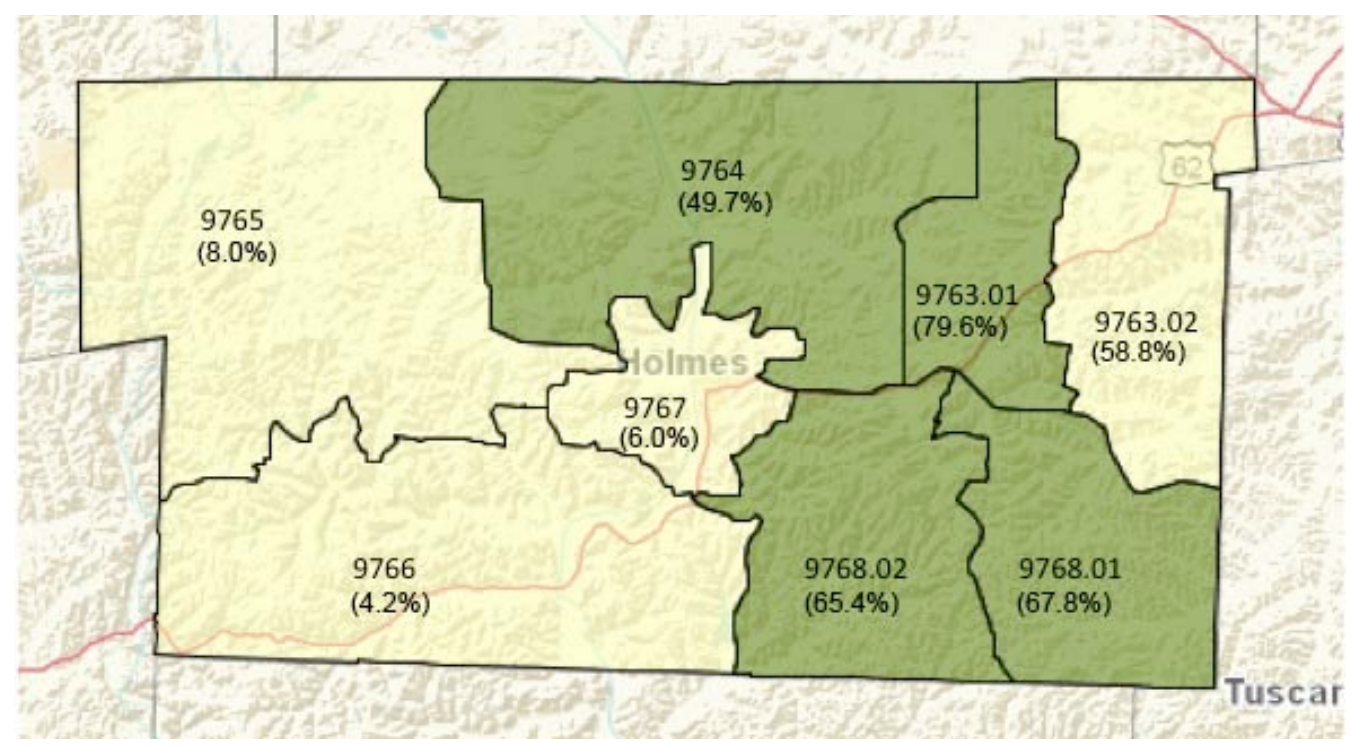

The Census asks three questions related to language spoken at home: "(1) Does this person speak a language other than English at home? (Yes, No); (2) What is this language? (For Example: Korean, Italian, Spanish, Vietnamese); and (3) How well does this person speak English? (Very well, well, not well, not at all)” (U.S. Census Bureau 2010). The A.C.S. questionnaire records the exact language. However, because of the Census's mandate to preserve anonymity by geographic area, we are constrained to an aggregate classification "other IndoEuropean language” in this Census Tract as an Amish marker. Pennsylvania Dutch is classified as “other West-Germanic languages” within the “other Indo-European languages” group. We use the latter category to estimate the Amish populations in each Census Tract in Holmes County. According to the 2010 Census estimates, $80.4 \%$ of the population in Census Tract 9763.01 spoke “other Indo-European Languages.” Within this group, the vast majority spoke Germanic languages with a tiny percentage-only $0.92 \%$ of the population — that spoke Polish. When we remove this group, this Census Tract contains 79.6\% who are likely Amish.

To ensure our results were reliable, we used language spoken at home and checked population results against Donnermeyer, Anderson, and Cooksey’s $(2013,100)$ estimates derived from the 2010 Amish Directory, The Budget, and Raber's Almanac. They find that the Amish number 17,042 in Holmes County and are 40.71\% of the population. The 2010 A.C.S estimates put the number of Amish in Holmes County at 16,323 or $39.59 \%$ of the population. We are able to statistically confirm that other indicators, such as fertility, family size, male-female families, and education match what we know about the Amish when we use language spoken at home as a marker. The reasonable closeness between the A.C.S. and Donnermeyer, Anderson, and Cooksey's $(2013,100)$ numbers suggests that language spoken at home, specifically the aggregate category “other Indo-European Languages,” is a reasonable indicator of the Holmes 
County Amish population. We focus our income and poverty analysis on Census Tract 9763.01 because it has the highest estimated percentage of Amish.

\section{Obtaining Wealth Data as Proxied by Land Values}

To understand wealth distribution in Census Tract 9763.01, we cross-referenced individuals from the Amish Directory for the Greater Holmes County Settlement ${ }^{2}$ with land title data from the Holmes County auditor website. Land values are good indicators of accumulated wealth and have been used in previous research. ${ }^{3}$ First, we used the Directory to determine which church districts are within Census Tract 9763.01. To do this, we superimposed Census Tract 9763.01 on a Holmes County map and determined tract borders, which proved to be about 10 miles north to south and two miles west to east. We mapped out all the church districts which were wholly or partially in this Census Tract-11 Andy Weaver, 22 Old Order, and eight New Order. Then we selected two church districts from each of three main affiliations represented in the directory: Andy Weaver, Old Order, and New Order (as noted earlier, Swartzentrubers refuse to be listed in the directory). For each affiliation, we selected two church districts that were entirely within the Census Tract 9763.01 to obtain data from at least 50 individuals in each affiliation. After selecting church districts in this Census Tract, we used the Directory to obtain information about each head of household, including occupation and leadership standing within the church. Next we used the Holmes County auditor website to identify the land owned by each head of household or family member within the tract. The information from the Directory was then coded and analyzed in conjunction with the information about total acreage, land value, and land use from the Holmes County auditor. One limitation of this approach is that we cannot account for individuals in our sample who own land beyond Holmes County. ${ }^{4}$

To get a fuller sense of the distribution of Amish wealth across all four of the main affiliations in the Holmes County Settlement, we gathered a sample of 55 Swartzentruber households. To gather this sample, we drove through Census Tract 9763.01 and the adjacent Census Tract, Wayne 17. We looked for identifying characteristics of Swartzentruber homes, specifically red barns, numerous outbuildings, mud lanes, generally unkempt and plain appearance, plain/black metal mailboxes with handwritten names and addresses, or a stationary motor located next to the barn (Johnson-Weiner 2010). We then recorded the addresses and names of the houses we believed were owned by Swartzentruber individuals. Afterward, we verified that these addresses and names were absent from the Directory to ensure that we had not misidentified the family as Swartzentruber. After this check, we used the Holmes County and Wayne County auditors' websites to find data on acreage, land value, and land usage for each household, just as we did for the other three affiliations. After merging the data in the Directory with the information from the Auditors website, individual identifiers were purged from the file. Unfortunately, because the Swartzentrubers do not participate in the Directory, we were unable to record information about church leadership standing as we did for the members of the other affiliations. However, this sample did prove to be useful because it allowed us to compare land values between the four Amish affiliations. 


\section{Results}

\section{Household and Family Income}

We plotted the distribution of household and family income for Census Tract 9763.01 from the A.C.S. in 2010 (see Figure 2). As explained above, this Census Tract was selected because it contains the largest percentage of Amish in Holmes County. Comparing Ohio to national averages confirms that Ohio has lower incomes. Ohio has more households that have incomes below $\$ 50,000$ to $\$ 74,999$ and fewer households that have incomes above. Both Ohio and the national data show bell-shaped distributions, as expected. The tract that contains the most Amish is far from uniform, however. The distribution shows a significant number of families with incomes below $\$ 49,000$. Twenty three percent of households living in this Census Tract have average incomes of about $\$ 42,000$. More fascinating is the emergent mode at $\$ 75,000$. The histogram sharply dips down to $10.6 \%$ for $\$ 50,000$ to $\$ 74,999$ until it sharply peaks again at $15.9 \%$ for $\$ 75,000$ to $\$ 99,999$. Figure 2 suggests two distinct income classes may be developing in Census Tract 9763.01 not present in the rest of the county, state, or national averages. Contrary to perceptions and ethnographic studies that claim a flat community, the distribution of income in tract 9763.01 is not uniform. Further, the coefficient of variation, the normalized measure of dispersion, is not significantly different between Holmes-9763.01 and Ohio. This calls into question our assumption that the standard of deviation in Amish household incomes is smaller.

We compare the distribution of family income in 2010 with 2000 in this same Census Tract (see Figure 3). ${ }^{5}$ The data suggests increasing average incomes due to the economic changes in Holmes County and an emerging bi-modal income distribution with peaks at $\$ 35,000$ to $\$ 49,000$ and $\$ 75,000$ to $\$ 99,999$.

To ensure that this is not a one-off result, we explored the family income distribution estimates for both Salt Creek Township as a whole and the portion of Salt Creek Township which is in Census Tract 9763.01, as reported by the A.C.S. We chose Salt Creek Township because the population in this township located within Census Tract 9763.01 is $84 \%$ Amish (see Appendix B for more details). The emerging income division among the Amish is also apparent in Salt Creek Township and the Salt Creek / 9763.01 section in 2010 (see Figure 4). In the Salt Creek part of 9763.01, the emerging income dispersion is more dramatic. The A.C.S. reports $42.68 \%$ of the families live on $\$ 35,000$ to $\$ 49,999$ and less than five percent live on $\$ 50,000$ to $\$ 74,999$, yet $19 \%$ earn between $\$ 100,000$ and $\$ 149,999$. Although there is a possibility that all of the people earning about $\$ 100,000$ or more are non-Amish, it is unlikely. Such a possibility would require that the entire non-Amish population in the tract-roughly $20 \%$-earn more than $\$ 100,000$. This is possible but highly improbable.

We hypothesize that the changes in income between 2000 and 2010 in the Salt Creek / 9763.01 section reflect visible economic changes in the larger Amish community. These changes could be due to the large number of Amish who have begun to branch out of the agricultural field 
Figure 2: Household Income in the Past 12 months for 2010

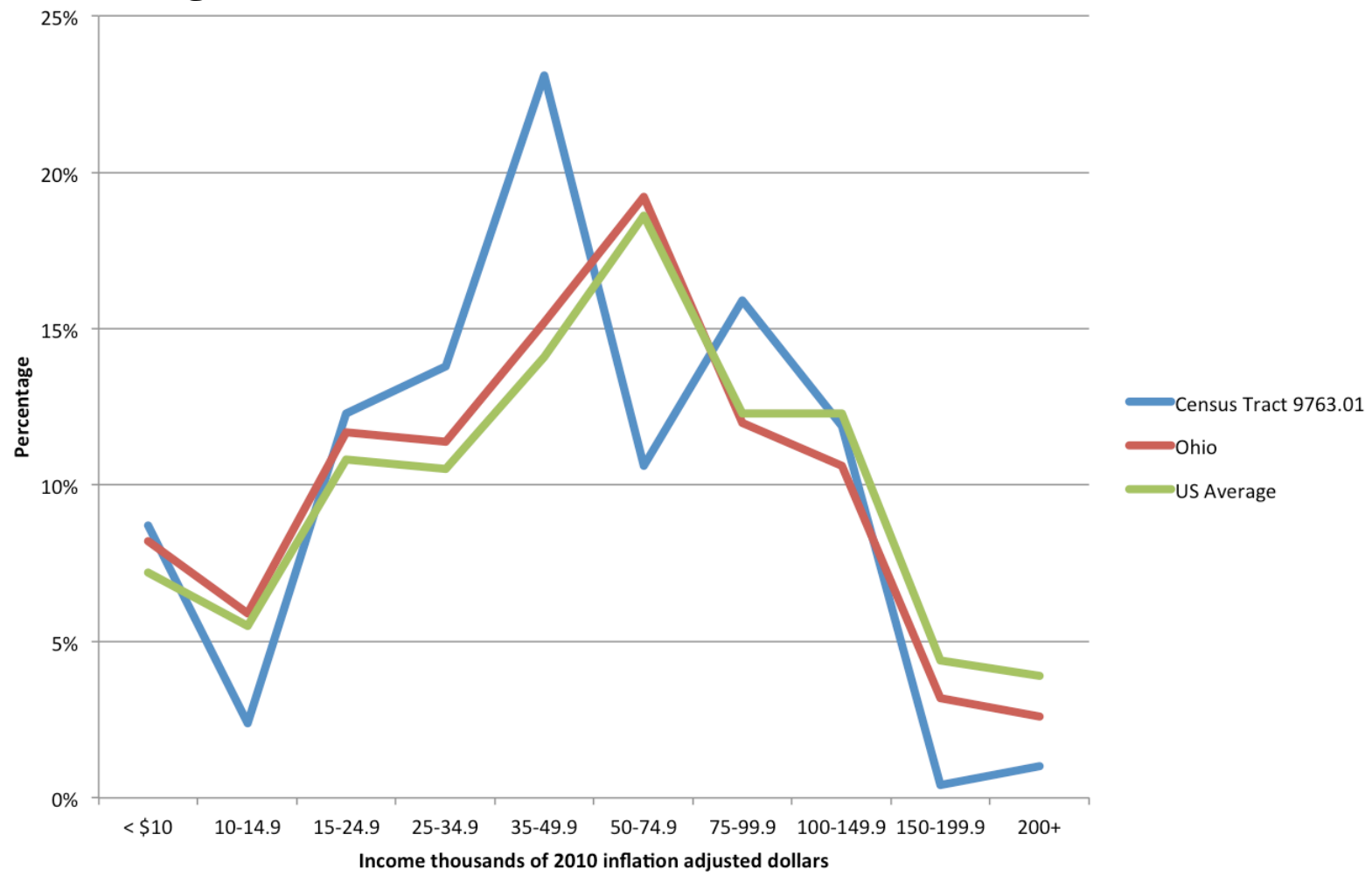

Source: American Community Survey, United States Census. Accessed August 2013.

Figure 3: Family Income 2000 vs. 2010

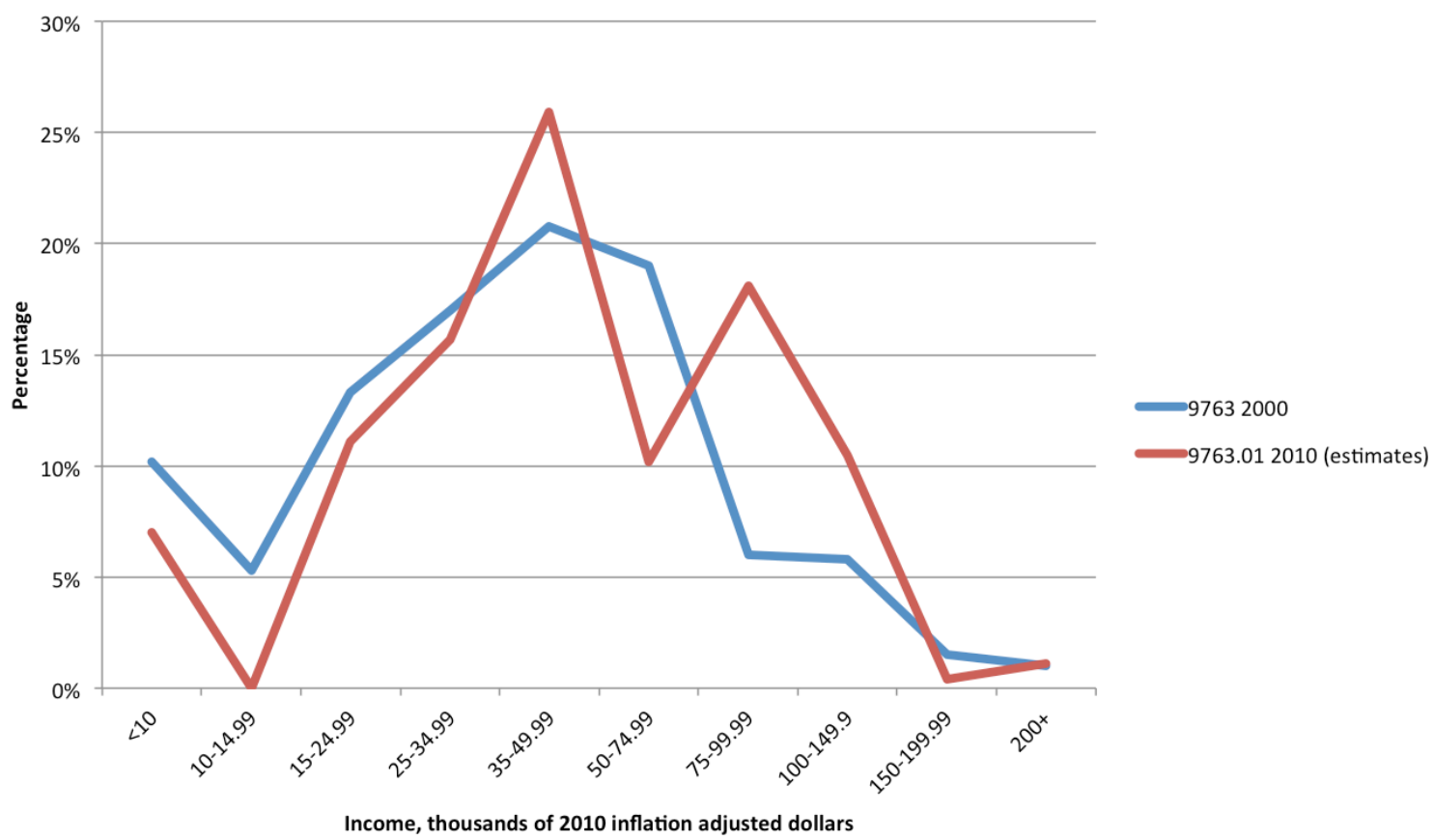

Source: American Community Survey, United States Census. Accessed August 2013. 


\section{Figure 4a Family Income Salt Creek}

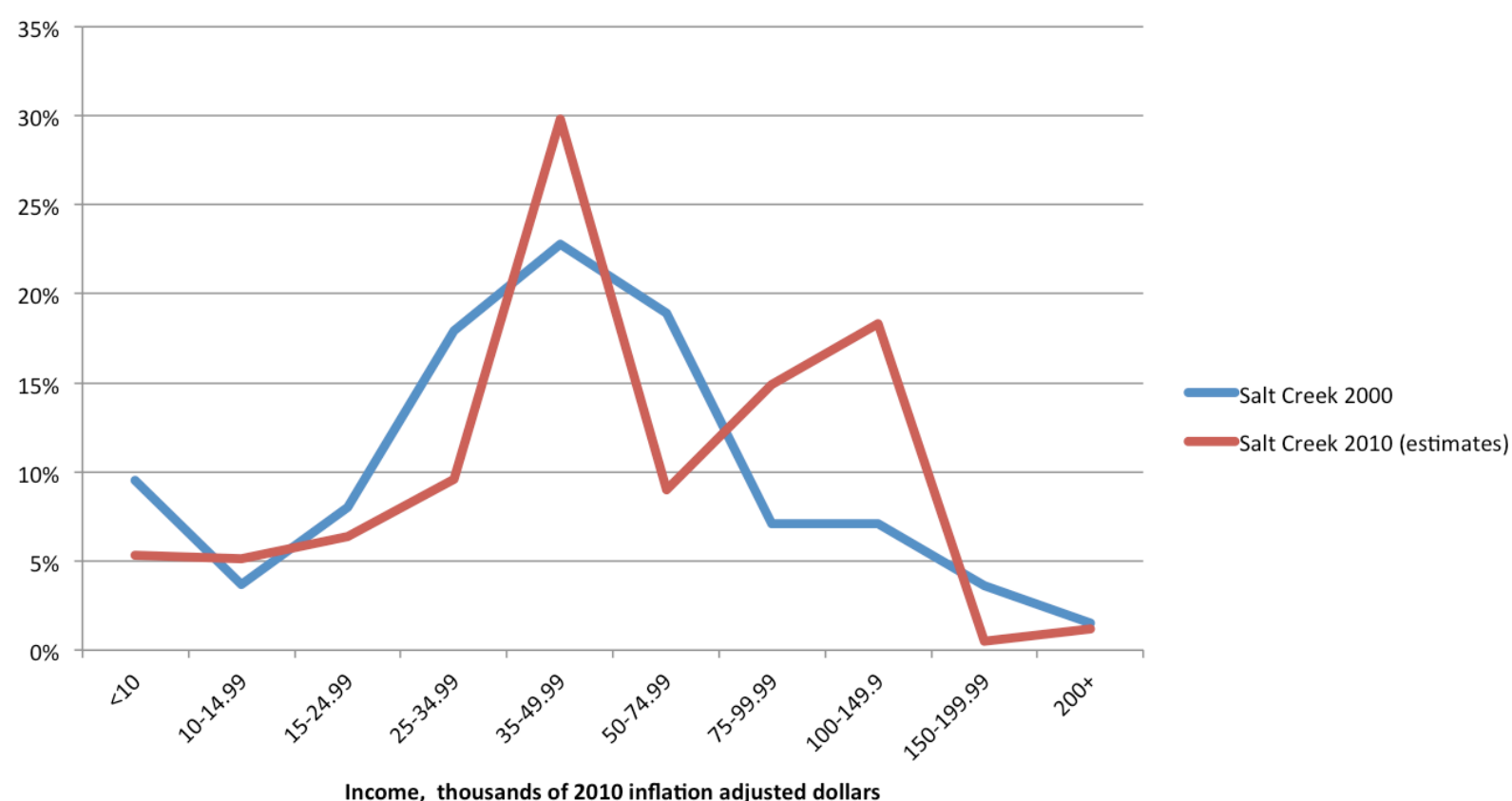

Source: American Community Survey, United States Census. Accessed August 2013.

Figure 4b Family Income Salt Creek / 9763.01 Section

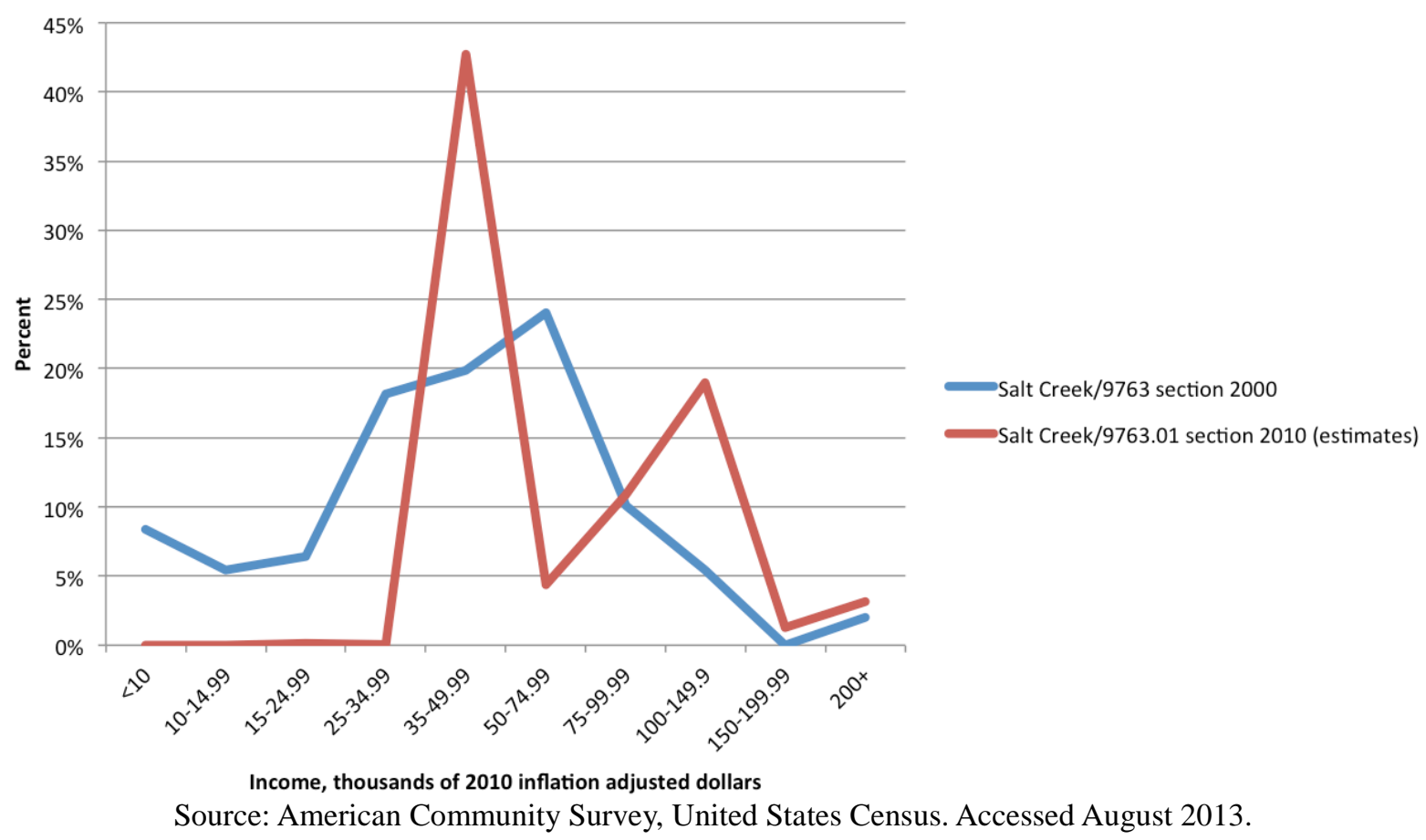


and into others, such as furniture, hardware, and handicrafts, as documented in Smith, et al. (1997). These new enterprises may have allowed some Amish to rise into a higher income bracket, while others remain in the $\$ 35,000$ to $\$ 49,999$ bracket. Depending on the size of the family, many people within this lower bracket fall under the Census poverty line. This is consistent with A.C.S. data that estimates that $18.28 \%$ of people in the Salt Creek / 9763.01 section and $22.28 \%$ of Amish in the area live below the national poverty line.

The newly emerging distribution of wealth in a heavily Amish populated area follows a non-normal distribution pattern that differs from any previous distributions. The once egalitarian Amish society may be changing to one with differentiated income classes, potentially due to Amish entanglement with non-agricultural ways of life.

\section{Rates of Poverty}

We identify the Amish by language spoken at home in tract 9763.01, Salt Creek Township, and the Salt Creek / 9763.01 section (see Table 2). Our results suggest that a disproportionately large number of Amish individuals in Census Tract 9763.01 have incomes below national poverty levels. We used a chi-square test to ascertain if the average poverty rates between the likely Amish and non-Amish are equal; results suggest statistical difference.

\section{Table 2: Poverty Rates (2010 estimates)}

\begin{tabular}{l|cc} 
Location & Amish population & All persons \\
\hline Salt Creek Twp. & $22.29 \%$ & $18.17 \%$ \\
Census Tract 9763.01 & $25.35 \%$ & $21.20 \%$ \\
Salt Creek Twp. / 9763.01 & $28.88 \%$ & $24.36 \%$ \\
Holmes County & $18.75 \%$ & $12.16 \%$ \\
Ohio & - & $13.42 \%$ \\
United States & - & $13.21 \%$
\end{tabular}

Source: American Community Survey, United States Census. Accessed August 2013.

Implications about poverty among the Amish based on U.S. Census poverty rates may be misleading. Since Amish church districts engage in barter and sharing economies, the cost of living as an Amish family may be lower than federal poverty rates would assume. The Amish have chosen a simpler life, producing much of what they consume. Most prohibit the use of electricity from the grid and the ownership of automobiles; hence, their cost of living is also lower because of lifestyle choices (Higgins and Evans 2009). The Amish also have large families. Because of low incomes and large families, Amish are more likely to be listed as living in poverty. While these results may not point to a lower quality of life per se, they do confirm the large numbers of the Amish that we find at the lower modal peak in the earlier income analysis. 


\section{Social Assistance Programs}

We looked at the social assistance program participation rates among the likely Amish in the A.C.S., again identified by language spoken at home. Social assistance programs include social security, supplemental security income, cash public assistance and Food Stamps/SNAP benefits for each area of interest in 2000 and 2010. The most significant finding from Table 3 is the percentage of people who collected Food Stamps / SNAP benefits in 2010. ${ }^{6}$ In Ohio, 11.0\% of people collected Stamps / SNAP benefits while only 1.6\% do so in tract 9763.01. Zero percent did so in the Salt Creek subdivision and Salt Creek / 9663.01 section. Despite high poverty levels, our results show low SNAP participation. According to Hurst and McConnell (2010, 178), the Amish discourage governmental social assistance and refrain from collecting food stamps. This can especially be seen in the Salt Creek subdivision where $100 \%$ of the people below the poverty line are likely Amish and yet $0 \%$ of the population receives food stamp benefits. Some Amish do appear to claim social security benefits. Twenty-seven percent of the population in Tract 9763.01 receives social security. This result is significant if we couple it with the knowledge that approximately $80 \%$ of this tract is Amish. We can reasonably conclude that a small number of the Amish receive social security benefits, despite the fact that the practice is discouraged in most church districts.

\section{Table 3: Poverty Rate and Food Stamps}

\begin{tabular}{l|cc} 
Location & Poverty rate (all persons) & Food Stamp / SNAP benefit receipt \\
\hline Salt Creek Twp. & $18.17 \%$ & $0.00 \%$ \\
Census Tract 9763.01 & $21.20 \%$ & $1.60 \%$ \\
Salt Creek / 9763.01 & $24.36 \%$ & $0.00 \%$ \\
Holmes County & $12.16 \%$ & $5.40 \%$ \\
Ohio & $13.42 \%$ & $11.00 \%$ \\
United States & $13.21 \%$ & $9.30 \%$
\end{tabular}

Source: American Community Survey, United States Census. Accessed August 2013.

\section{Wealth Distribution by Affiliation}

As outlined in our methodology, we wanted to differentiate between flows and stocks of economic opportunity. Land ownership is an excellent indicator of accumulated wealth; numerous studies have used it to examine wealth inequality. To obtain the histograms below, we cross-referenced data from households listed in the Directory that were in Census Tract 9763.01 with land values and acres owned from Holmes and Wayne County Auditor's websites. The county auditor's website has detailed property cards for all county land, searchable by name and address. The Amish own considerable and valuable land. For our sample of 178 individuals who 


\section{Figure 5: Amish Wealth Distributions: Acres and Nominal Value}

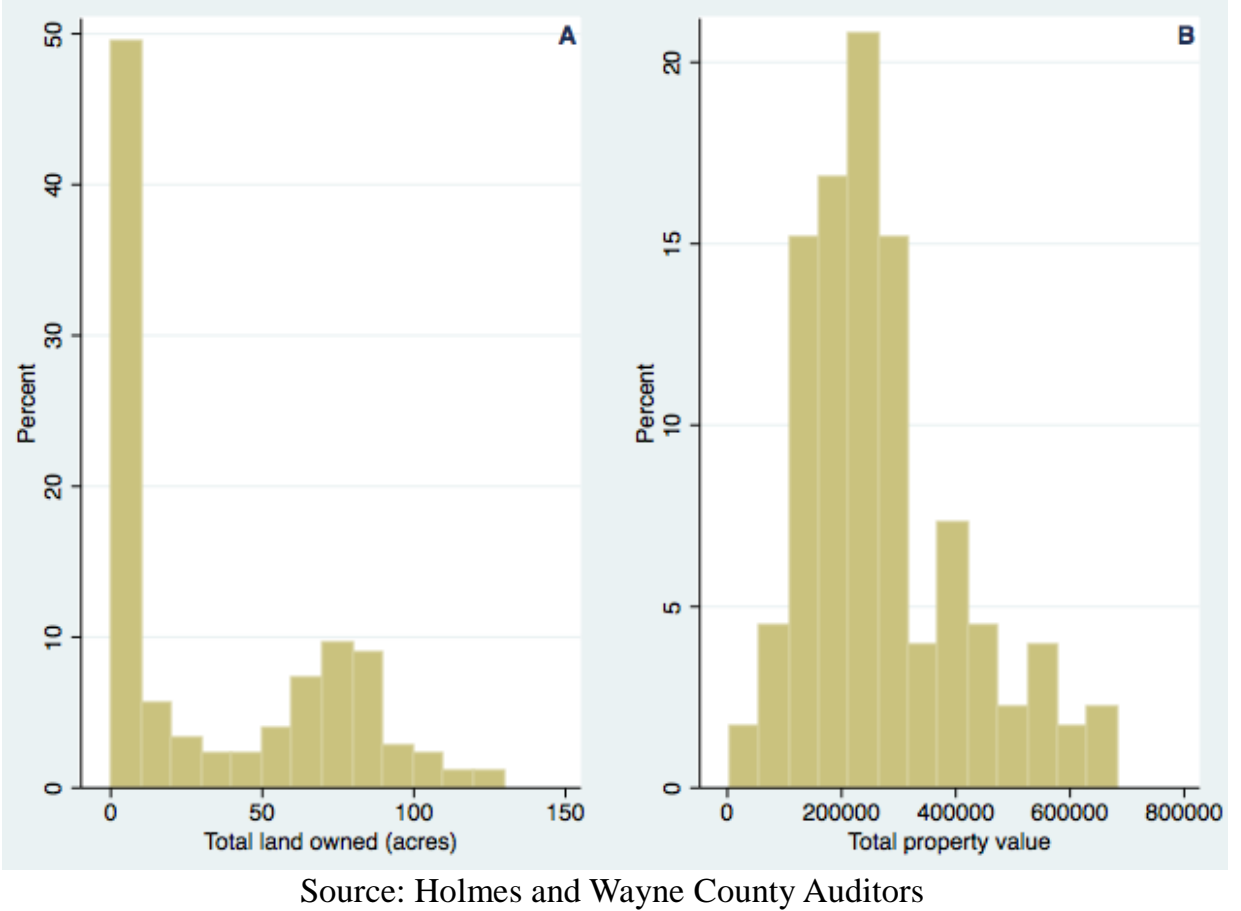

held land titles, the average total property values across all affiliations was $\$ 269,270.50$; average acres owned was 34.74. The land ownership data confirm the emergent bimodal tendency we observed in the income data (Figure 5).

The distribution within and between orders tells a more nuanced story (Table 4). The Swartzentruber Amish own significantly larger amounts of acreage per person than those in other affiliations. Although the Andy Weavers are next in terms of acreage, the median acreage is only 6.03 acres. The data suggests that the vast majority of Andy Weaver, Old Order, and New Order Amish in our sample have very modest land holdings of less than ten acres. While, the directory data for our sample suggest fewer farmers among the Andy Weavers, they do appear to be maintaining their land holding sizes. The Swartzentrubers also have the most uniform land acreage distribution (Figure 6), confirming other studies that suggest they are preserving the agricultural lifestyle (Johnson-Weiner 2010; Hurst and McConnell 2010).

Close to a quarter of the Andy Weaver sample own a considerable amount of land, suggesting that although most have moved out of dairy farming due to the prohibition on bulk milk tanks, some have held on to sizeable (over 50 acres) tracts of land. Anecdotally, we learned that this acreage is being used for produce farming, raising sheep, and even caring for heifers for industrial farms. In the distribution of land across all affiliations, we see the emergence of individuals who own very large land tracts and those who do not. This is more pronounced in the Old and New Order affiliation, however, and aligns well with the bimodal distribution of incomes emerging in the 2010 Census data. 


\section{Table 4: Land Ownership by Affiliation}

\begin{tabular}{l|cccc} 
Affiliation & $\mathrm{n}$ & Mean (Acres) & Median (Acres) & Std. Deviation \\
\hline Swartzentruber & 55 & 60.69 & 69.36 & 31.94 \\
Andy Weaver & 38 & 25.74 & 6.03 & 32.95 \\
Old Order & 41 & 20.35 & 4.00 & 31.77 \\
New Order & 44 & 23.50 & 7.94 & 33.60
\end{tabular}

\section{Figure 6: Total Acres Owned by Affiliation}

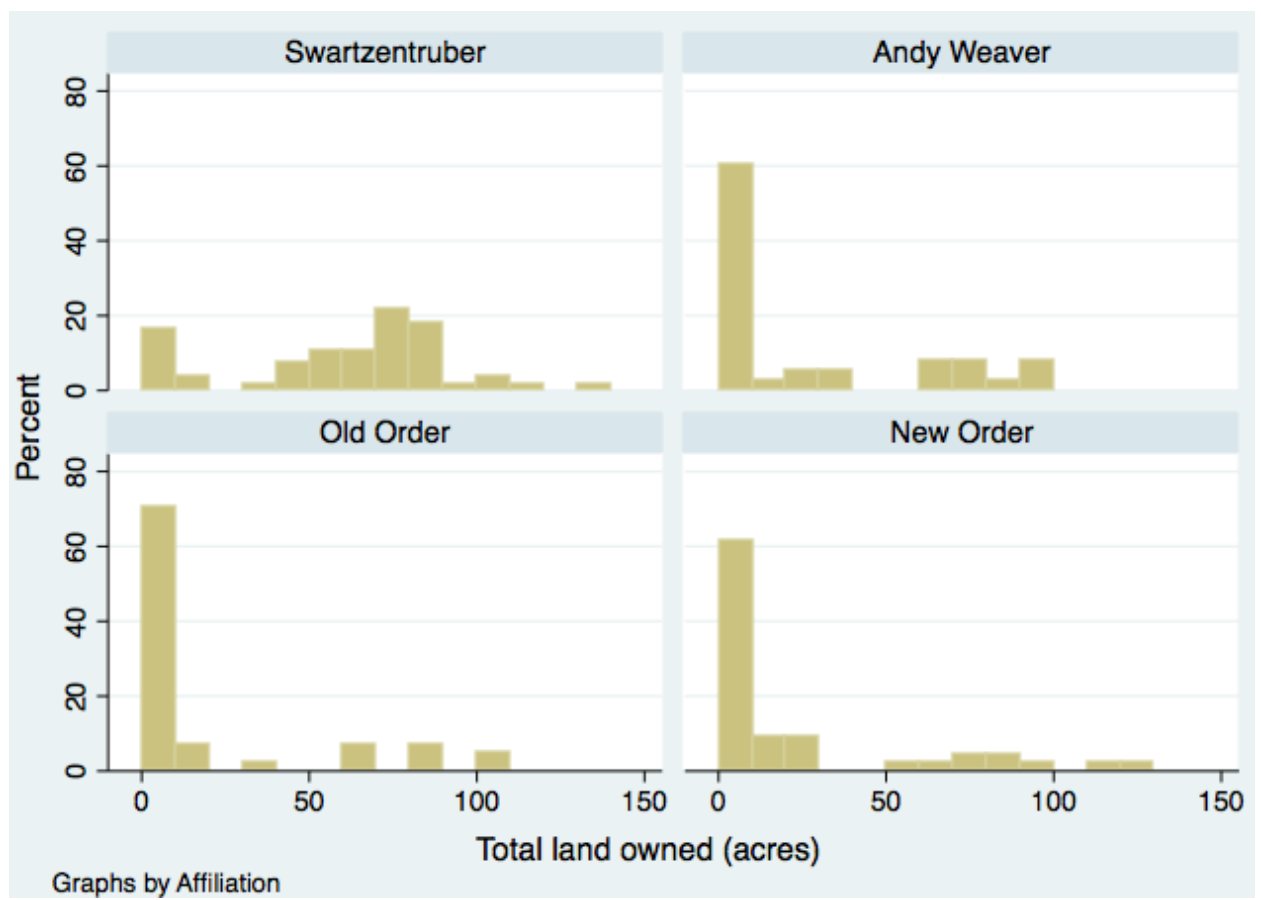

We conducted t-tests to determine if the mean acreage owned and total land values were significantly different between farmers and non-farmers. Farmers own more land than nonfarmers, with an average of 61.25 acres for farmers and 11.28 acres for non-farmers. The average land value for farmers was $\$ 272,272.10$ and $\$ 225,284.9$ for non-farmers. The choice of profession does affect land ownership and wealth (see Appendix A).

Frequency distributions of affiliations' land values generally follow a normal distribution (Figure 7), with Swartzentrubers being the most evenly distributed. Our Swartzentruber sample appears land rich compared to other affiliations. The New Order has a slight upward peak to the graph’s right, showing that few members within our sample have land values around $\$ 600,000$. 


\section{Figure 7: Total Property Value by Affiliation}

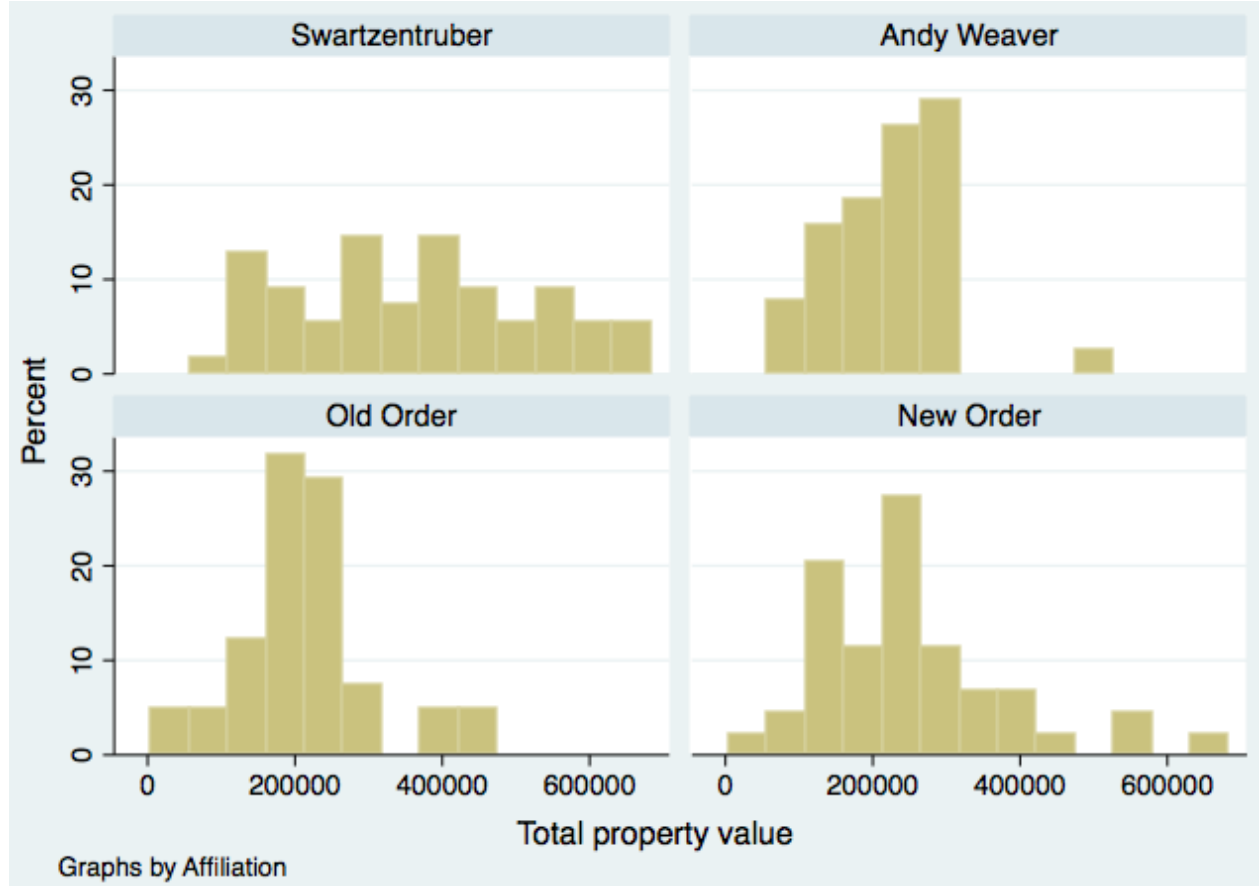

Frequency distributions were also constructed showing total land values by church rank across members of all affiliations. Total land values for church members followed a normal distribution as expected. Total land values from deacons, ministers, and bishops also followed normal distributions. However, as church rank increased from member to bishop, the distribution seemed to skew to the right, bishops having the highest total land values, suggesting church rank is associated with higher land wealth. Rather than trust our visual acuity, simple probit regressions suggest that land wealth and church rank are significantly related (see Appendix A).

\section{Conclusion}

In this exploratory study, we triangulated data from three major sources- the U.S. Census, the Ohio Amish Directory, and the Holmes County Auditor's web site- to map out the distribution of income and land wealth in one predominantly Amish Census Tract in Holmes County, $\mathrm{OH}$. Our findings show economic differentiation within this Amish population in several ways. First, Amish income distribution shows a bimodal tendency, which has emerged between 2000 and 2010, that is more pronounced than the state or national distributions. Second, Amish in this Census Tract have higher rates of poverty than the national average, yet low rates of social assistance. Third, church leadership is positively and significantly correlated with both land holdings and land values. Finally, Swartzentruber families on average own larger and more evenly distributed acreage than the Andy Weaver, Old Order, and New Order affiliations.

Our study corroborates the findings of qualitative studies on transformations in Amish economic livelihoods. For example, our results confirm a trend that Kraybill and Nolt (2004) 
first pointed out in their study of Lancaster County Amish enterprises: new income and wealth has been introduced into Amish communities from the success of growth-oriented businesses. Kraybill and Nolt argue that the rise of burgeoning businesses "contain the seeds of a three-class society consisting of farmers, entrepreneurs, and day laborers” (221). Our findings suggest that these seeds have germinated, though it remains to be seen how they will grow over time.

Our study also points to some fruitful avenues and questions for future research. To begin, how do successful Amish businessmen, including the growing number of Amish millionaires, spend their discretionary income? How do they attempt to disguise their wealth, and what do they and others see as legitimate and illegitimate types of spending? It would also be interesting to explore how the types and impacts of social leveling mechanisms have changed over the past few decades. Do Amish church members tend to downplay the significance of wealth and income inequalities as long as the wealthy members of their community use their assets to support agreed-upon needs in the church district or larger community? And how is that larger community defined? We also know very little about how Amish families try to reproduce their social and economic status. How do they approach estate planning and inheritance and try to pass on their social and economic capital to the next generation? These questions take on new urgency in light of the staggering size of payouts for gas leases and wells that are beginning to trickle into some Amish communities in Pennsylvania and southeastern Ohio (Redden 2013).

Our study also suggests that the relationship between land wealth and church leadership merits further exploration. Kraybill and Nolt (2004, 215-16) first highlighted the growing tendency in predominantly non-farming church districts for ordained leaders to be businessmen. They further noted a generational change in this respect, with younger church members expressing fewer concerns about having a bishop who runs a business. Our study does not weigh in on a causal mechanism for the association between landholdings and church leadership status, but it would be interesting to explore. Are church members more likely to nominate candidates for deacon, minister, and bishop if they have significant land holdings? Or do these differences arise after a church member is ordained, and if so, how and why?

Our study has a number of significant limitations. One is its focus on only one Census Tract in one county in one very distinctive Amish settlement. We had good reasons for choosing this Census Tract for our analysis, but its proximity to the tourist center of Berlin, OH, may mean residents have higher incomes and wealth than Amish who are farther away. In addition, about $20 \%$ of Census Tract residents studied here are non-Amish. For income data only, Census rules prohibit us from disentangling the Amish from the non-Amish. As such, our results should be treated carefully. They do support the findings of other ethnographic studies, and wealth / poverty data also corroborate our assertions. In future research we hope to look at a national 1\% sample of the Amish by language spoken at home. Finally, our study does not adequately assess change over time, especially since the move away from farming gained steam in the 1970s and 1980s. The U.S. Census Bureau has just released county-level data for 1940, for example, making possible a comparative study that goes back even further. 
In addition to expanding our research across time periods, our approach can be applied to other Amish and plain Anabaptist-dominated Census Tracts, as in Elkhart / LaGrange Counties, Indiana. However, the difficulties in locating Census Tracts that are predominantly Amish in currently available Census data limit the areas where this methodology can be effectively employed. While a 90\% or higher concentration of Pennsylvania Dutch speakers in a given Census Tract is ideal for increasing the study reliability, we found approximately $80 \%$ and higher to be an acceptable Census Tract threshold for analytical selection. If the Amish population continues its exponential growth, the number of such Census Tracts will likely increase.

In spite of these limitations, our findings suggest that the move away from farming is reconfiguring Amish communities' economic landscape in important ways. Until recently, the powerful combination of religious principles, cultural sensibilities, and a farming tradition was enough to insulate the Amish from capitalism's more negative effects. The evident success of Amish-owned businesses and the corresponding rise of an entrepreneurial class will likely test the cultural and religious fabric of Amish life in coming years in ways hard to imagine.

\section{Endnotes}

${ }^{1}$ Contact information: Amyaz A. Moledina, Associate Professor, Department of Economics, College of Wooster, Wooster, Ohio 44691; amoledina@wooster.edu 330-263-2287

${ }^{2}$ Hereinafter referred to as the Directory.

${ }^{3}$ Benjamin, J. D., Chinloy, P., \& Jud, G. D. 2004. "Real Estate versus Financial Wealth in Consumption.” Journal of Real Estate Finance and Economics 29(3), 341-354. They show that real estate wealth and consumption are more strongly related than other sources of financial wealth like equities, savings accounts and mutual funds.

${ }^{4}$ Because it was relatively simple to do, we did check for land ownership in Wayne County. So individual data records both Wayne and Holmes property ownership. However, we did not do this for other counties.

${ }^{5}$ We compare 2000 Census and the 2010 Census five year estimates. 9763.01 data is not available for 2000. Also we do a similar analysis for family income. Our results of family income and household income are remarkably similar. According to the Census, family income measures the income of persons who live in the same household and are related by birth, marriage, or adoption. Household can include people that are living in the same household but unrelated. Since the Amish in Holmes County tend to live within extended family units, it is not surprising that family and household incomes are similar.

${ }^{6}$ Food Stamps / SNAP data unavailable for 2010. 


\section{References}

Applied Population Laboratory. 2002. SPG Report on Wisconsin's Old Order Amish Population. Madison, WI: University of Wisconsin-Madison.

Bailey, Martha J. and William J. Collins. 2009. Did Improvements in Household Technology Cause the Baby Boom? Evidence from Electrification, Appliance Diffusion, and the Amish. Report No. w14641. National Bureau of Economic Research.

Christie-Searles, John B. 2012. “Amish and Their Effect on Per Capita Incomes in Pennsylvania.” The Heinz Journal 9(1):1-9.

Craker, Lorilee. 2011. Money Secrets of the Amish. Oasis Audio.

Donnermeyer, Joseph F. and Elizabeth C. Cooksey. 2010. "On the Recent Growth of New Amish Settlements.” Mennonite Quarterly Review 84(2):181-206.

Donnermeyer, Joseph F., Cory Anderson, and Elizabeth C. Cooksey. 2013. “The Amish Population: County Estimates and Settlement Patterns.” Journal of Amish and Plain Anabaptist Studies 1(1):72-109.

Higgins, Will and Tim Evans. 2009. “Downturn Puts Amish in Bind.” USA Today June 30:3a.

Hostetler, John A. 1993. Amish Society. Baltimore, MD: Johns Hopkins University Press.

Hurst, Charles E. and David L. McConnell. 2010. An Amish Paradox: Diversity and Change in the World's Largest Amish Community. Baltimore, MD: Johns Hopkins University Press.

Johnson-Weiner, Karen M. 2010. New York Amish: Life in the Plain Communities of the Empire State. Itahaca, NY: Cornell University Press.

Kreps, George M., Joseph F. Donnermeyer, Charles Hurst, Robert Blair, and Marty Kreps. 1997. "The Impact of Tourism on the Amish Subculture: A Case Study." Community Development Journal 32(4):354-67.

Kraybill, Donald B. 2003. The Amish and the State. Baltimore, MD: Johns Hopkins University Press.

Kraybill, Donald B. 2001. The Riddle of Amish Culture. Baltimore, MD: Johns Hopkins University Press.

Kraybill, Donald B. and Steven M. Nolt. 2004. Amish Enterprise: From Plows to Profits. Baltimore, MD: Johns Hopkins University Press.

Kraybill, Donald B, Karen M. Johnson-Weiner, and Steven M. Nolt. 2013. The Amish. Baltimore, MD: Johns Hopkins University Press. 
Markle, Gerald E. and Sharon Pasco. 1977. "Family Limitation Among the Old Order Amish.” Population Studies 31(2):267-80.

Meyers, Thomas J. 1994. “Lunch Pails and Factories.” Pp. 165-81 in The Amish Struggle with Modernity, edited by Donald B. Kraybill and Marc A. Olshan. Hanover, NH: University Press of New England.

Meyers, Thomas J. 2003. “Amish Tourism: 'Visiting Shipshewana is Better than Going to the Mall.”” Mennonite Quarterly Review 77(1):109-26.

Nolt, Steven M. and Thomas J. Meyers. 2007. Plain Diversity: Amish Cultures and Identities. Baltimore, MD: Johns Hopkins University Press.

Olshan Marc A. 1991. "The Opening of Amish Society: Cottage Industry as Trojan Horse.” Human Organization 50(4):378-84.

Putnam, Robert D. 2013. “Crumbling American Dreams.” New York Times August 4: SR9.

Redden, Molly. 2013. “The Amish Are Getting Fracked.” New Republic June 6:1-14.

Smith, Stephen M., Jill L. Findeis, Donald B. Kraybill, and Steven M. Nolt. 1997.

"Nonagricultural Micro-enterprise Development Among the Pennsylvania Amish: A New Phenomenon,” Journal of Rural Studies 13(3):237-51.

Testa, Randy-Michael. 1992. After the Fire: The Destruction of the Lancaster County Amish. Hanover, NH: University Press of New England.

Trollinger, Susan L. 2012. Selling the Amish: The Tourism of Nostalgia. Baltimore, MD: Johns Hopkins University Press.

U.S. Census Bureau. 2008. A Compass for Understanding and Using American Community Survey Data: What General Data Users Need to Know. Retrieved July 17, 2013 (http://www.census.gov/acs/www/Downloads/handbooks/ACSGeneralHandbook.pdf)

U.S. Census Bureau. 2010. Language Use: Frequently Asked Questions. Retrieved July 15, 2013 (http://www.census.gov/hhes/socdemo/language/about/faqs.html)

Wang, Liang Choon. 2009. Making Sect Life Better: Amish Prohibition of High School Education. Unpublished paper. San Diego, CA: University of California-San Diego.

Wasao, Samson and Joseph F. Donnermeyer. 1992. “An Analysis of Factors Related to Parity among the Amish in Northeast Ohio.” Population Studies 50(2):235-46.

Wesner, Erik. 2010. Success Made Simple: An Inside Look at Why Amish Businesses Thrive. New York: Jossey Bass. 


\section{Appendix A}

The table below shows the results from a t-test of the equality of means. The goal is to test if Amish farmers have amounts of land and property values that are statistically different from non-farmers. The results of a two-tailed statistical test [Diff=mean(farmer)-mean(nonfarmer) $\mathrm{H}_{0}$ :diff=0] suggest that farmers own more acreage and that farmer land values are higher. Statistical tests aside, Amish farmers own more than four times the acreage of the non-farming (see column three and compare the means for farmers and non-farmers).

\section{Table 5: t-Tests of Equality of Means}

\begin{tabular}{|c|c|c|c|}
\hline \multirow{2}{*}{ Categorical variable } & \multicolumn{3}{|c|}{ Variable: Total land owned (acres) } \\
\hline & Obs & Mean & Standard deviation \\
\hline \multirow{2}{*}{$\begin{array}{l}\text { Non-farmer } \\
\text { Farmer }\end{array}$} & 96 & 13.17 & 23.10 \\
\hline & 27 & 58.60 & 36.94 \\
\hline \multirow{2}{*}{$\begin{array}{r}\text { Combined } \\
\text { Diff }=\text { mean(farmer)-mean(n }\end{array}$} & 123 & 23.14 & 32.60 \\
\hline & \multicolumn{3}{|c|}{ Diff=mean(farmer)-mean(non farmer) $\mathrm{H}_{0:}$ diff $=0 \quad \mathrm{H}_{\mathrm{a}}$ : $\mathrm{diff}<0 \mathrm{t}$} \\
\hline \multirow{2}{*}{ Categorical variable } & \multicolumn{3}{|c|}{ Variable: Total property value (\$) } \\
\hline & Obs & Mean & Standard deviation \\
\hline Non-farmer & 96 & $221,994.9$ & $98,106.36$ \\
\hline \multirow{3}{*}{$\begin{array}{r}\text { Combined } \\
\text { Diff=mean(farmer)-mean( } \mathrm{n}\end{array}$} & 27 & $256,296.3$ & $127,430.2$ \\
\hline & 123 & $229,524.5$ & $105,634.5$ \\
\hline & Diff $=$ mean(farmer)-mean(non farmer) $\mathrm{H}_{0:}$ diff $=0$ & \multicolumn{2}{|c|}{$\mathrm{H}_{\mathrm{a}}: \operatorname{diff}<0 \mathrm{t}=-1.50$, d.f. $121 \operatorname{Pr}(\mathrm{T}<\mathrm{t})=0.06$} \\
\hline
\end{tabular}

The goal of ordered probit regression is to test if the progression in church rank, from member to bishop, is related to wealth, as proxied by total property values. The regression accounts for the effects of number of children and Amish order. We also use an indicator (dummy) variable to capture if the individual is a farmer. This regression is executed on individual household data, complied by cross-referencing data from households listed in the Directory that were in Census Tract 9763.01 with land values and acres owned from the Holmes County Auditor's website.

The results reported below show that the independent variables, property values, children, famers, and order, are strongly correlated with the dependent variable, church rank, as evidenced by chi square test results. We are $99.9 \%$ certain that the model is statistically significant. We also have strong statistical evidence to suggest that, controlling for other factors (cetris paribus), the number of children and total property values are highly correlated with church rank. We have insufficient evidence to reject the hypothesis that being a farmer or being in a different order makes the Amish more or less likely to progress through church ranks. 


\section{Table 6: Ordered Probit Regression}

\begin{tabular}{|c|c|c|c|}
\hline \multirow[t]{2}{*}{ Independent variable } & \multicolumn{3}{|c|}{ Dependent Variable: Church rank } \\
\hline & Coefficient & Std. Err & Z \\
\hline Total property value & $2.49^{-06} *$ & $1.39^{-06}$ & 1.79 \\
\hline Number of children & $.1572513 * * *$ & .0550684 & 2.86 \\
\hline Farmer (dummy) & .2272824 & .3187638 & 0.71 \\
\hline Order / affiliation & -.040747 & .1797161 & -0.23 \\
\hline Log likelihood & -69.151418 & & \\
\hline Number of observations & 123 & & \\
\hline LR chi2 (4) & 18.35 & & \\
\hline Prob > chi2 & 0.0011 & & \\
\hline
\end{tabular}

We caution the reader from imputing causality and magnitude from the results above. For example, with causality, it is quite possible that higher rank leads to more wealth rather than the other way around as specified in this estimation. The answer to this last question will be the subject of future research. All these regression results say is that controlling for other factors, the number of children and wealth are correlated with church rank. The higher the wealth, cetris paribus, the more probable that individual has a higher church rank. Also, the greater the number of children, cetris paribus, the more likely that individual has a higher church rank.

\section{Appendix B}

The Census uses the following hierarchy of geographic entities: nation $>$ regions $>$ divisions $>$ states $>$ counties $>$ Census Tracts $>$ block groups $>$ Census blocks. ${ }^{*}$ There are eight Census Tracts in Holmes County, numbered 9763.01, 9763.02, 9764, 9765, 9766, 9767, 9768.01, and 9768.02. The County can also be broken down into subdivisions, of which there are fourteen. Through the process described in the methodology, we were able to determine based on language spoken at home that there are two Census Tracts that have the highest concentrations of Amish inhabitants: 9763.01, with the Amish comprising $80.40 \%$ of the population, and 9768.01 , with $67.80 \%$.

Each tract covers a portion of a County Subdivision, called townships-Salt Creek Township corresponding with 9763.01 and Clark Township with 9768.01. As expected, both townships had high concentrations of Amish as well, with Salt Creek at 81.60\%, and Clark at $74.90 \%$. When we were able to locate in the Census data the section of overlap between Census Tract 9763.01 and Salt Creek Township, we found the highest concentration of Amish individuals: 84.34\%. Throughout this paper, we perform an exploratory study of 9763.01

*U.S. Census Bureau. Standard Hierarchy of Census Geographic Entities. Accessed July 15, 2013 (http://www.census.gov/geo/reference/pdfs/geodiagram.pdf) 